\title{
Methane conversion to hydrogen and nanotubes on Pt/Ni catalysts supported over spinel $\mathrm{MgAl}_{2} \mathrm{O}_{4}$
}

\author{
Giselle De B. Nuernberg ${ }^{\mathrm{a}}$, Humberto V. Fajardo ${ }^{\mathrm{b}}$, Edson L. Foletto ${ }^{\mathrm{c}}$, Sonia M. Hickel-Probst ${ }^{\mathrm{e}}$, \\ Neftalí L.V. Carreño ${ }^{d}$, Luiz F.D. Probst ${ }^{\mathrm{a}, *}$, Joel Barrault ${ }^{\mathrm{f}}$ \\ a Laboratório de Catálise Heterogênea, LABOCATH, Departamento de Química, Universidade Federal de Santa Catarina, 88040-900 Florianópolis, SC, Brazil \\ b Departamento de Química, Universidade Federal de Ouro Preto, 35400-000 Ouro Preto, MG, Brazil \\ c Departamento de Engenharia Química, Universidade Federal de Santa Maria, 97150-900 Santa Maria, RS, Brazil \\ d Departamento de Química Analítica e Inorgânica, Universidade Federal de Pelotas, 96010-900, Capão Leão, RS, Brazil \\ e Pro-reitoria de Pesquisa e Inovação Tecnológica, Universidade do Sul de Santa Catarina, 88137-270 Palhoça, SC, Brazil \\ ${ }^{\mathrm{f}}$ Laboratoire de Catalyse en Chimie Organique, ESIP, UMR CNRS 6503, 40 avenue du Recteur Pineau, 86022 Poitiers Cedex, France
}

\section{A R T I C L E I N F O}

Article history:

Available online 14 November 2010

\section{Keywords:}

Carbon nanotubes

Free-hydrogen

$\mathrm{Ni}-\mathrm{Pt}-\mathrm{MgAl}_{2} \mathrm{O}_{4}$ catalyst

Methane conversion

\begin{abstract}
A B S T R A C T
Methane decomposition is an endothermic process. Therefore a high temperature increases the methane conversion and improves the carbon accumulation. Nevertheless at high temperature conditions a faster deactivation of catalyst is generally observed. To keep the stability of the catalyst, lower reaction temperatures can be used as well as methane dilution but the catalytic activity is lowered. The aim of the present work consists in the study of the catalytic properties of $\mathrm{Ni}-\mathrm{Pt}$ supported over $\mathrm{MgAl}_{2} \mathrm{O}_{4}$ for the selective conversion of methane into hydrogen and carbon nanotubes.

The addition of a small amount of Pt to a nickel- $\mathrm{MgAl}_{2} \mathrm{O}_{4}$ catalyst promotes the formation of carbon nanotubes with a significant selectivity to MWCNT. The interest of using a bimetallic (Pt-Ni) catalyst is to favour the reduction of the Ni precursor (and the formation of small nickel particles).

For the catalyst that we prepared methane is mainly transformed into structured MWCNTs if the reduction is complete while graphitization is observed over partially reduced catalysts. A fine characterization of the catalyst surface after each step of the preparation and use is currently under investigation in order to progress in the relationships between the surface composition and the CNTs formation.
\end{abstract}

(C) 2010 Elsevier B.V. All rights reserved.

\section{Introduction}

Carbon nanotubes (CNTs) have become a category of the most actively investigated materials. Carbon nanotubes have a structure similar to graphene sheet rolled into a cylinder form with a diameter ranging from 0.8 to $300 \mathrm{~nm}$. Carbon nanotubes can be categorized into single-walled carbon nanotubes (SWNTs) and multi-walled carbon nanotubes (MWNTs) depending on the number of graphene layer. A concept of $\mathrm{CO}$-free hydrogen co-production for fuel cells from methane decomposition was proposed Li et al. [1]. Moreover it was postulated that metal particles are active for nanotubes nucleation and growth only if they are sufficiently small $(\leq 20 \mathrm{~nm})$ Dai et al. [2] and Amelinckx et al. [3].

\footnotetext{
* Corresponding author.

E-mail addresses: gi_qmc@hotmail.com (G.D.B. Nuernberg), hfajardo@hotmail.com (H.V. Fajardo), foletto@smail.ufsm.br (E.L. Foletto), sonia.hickel@unisul.br (S.M. Hickel-Probst),nlv.carreno@yahoo.com.br (N.L.V.Carreño), probst@qmc.ufsc.br (L.F.D. Probst), joel.barrault@univ-poitiers.fr (J. Barrault).
}

Methane decomposition is an endothermic process. Therefore a high temperature increases the methane conversion and improves the carbon accumulation. Nevertheless at high temperature conditions a faster deactivation of catalyst is generally observed. To keep the stability of the catalyst, lower reaction temperatures can be used as well as a methane dilution but the catalytic activity is lowered. The aim of the present work consists in the study of the catalytic properties of $\mathrm{Ni}-\mathrm{Pt}$ supported over $\mathrm{MgAl}_{2} \mathrm{O}_{4}$ for the selective conversion of methane into hydrogen and carbon nanotubes.

\section{Experimental part}

\subsection{Catalysts preparation}

First spinel-like compounds with an $\mathrm{Al}$ excess $\left(\mathrm{MgO}_{1} \cdot 4 \mathrm{Al}_{2} \mathrm{O}_{3}\right)$ were prepared. For the precursor synthesis, two solutions $(0.2 \mathrm{M}$ of $\mathrm{Mg}$ and $\mathrm{Al}$ alkoxides) using respectively methanol and isopropanol as solvents were mixed and heated to the alcohol boiling point, under vigorous stirring, then water (15\% of total alcohols volume) was added. The system is kept under heating and stirring to complete hydrolysis reaction. The formed material was separated from 


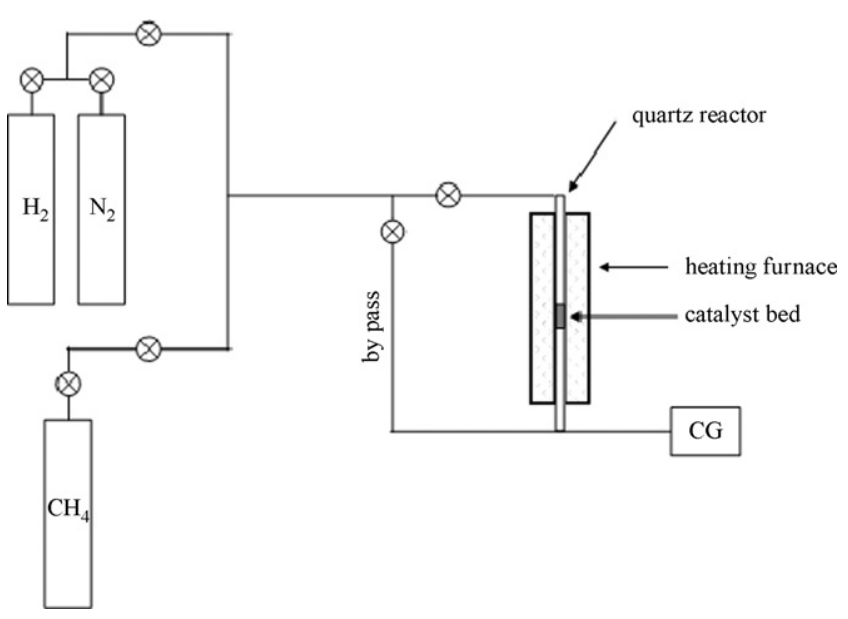

Fig. 1. Schematic diagram of the reactor system.

alcohols by filtration and further dried at $120^{\circ} \mathrm{C}$ for $24 \mathrm{~h}$. The fine powder was sieved (100 mesh) and calcined in air atmosphere at a temperature of $1100^{\circ} \mathrm{C}$ for $4 \mathrm{~h}$. The spinel support was then impregnated with a nickel nitrate solution in order to fit a nickel content of $15 \mathrm{wt} \%$ after air calcination at $700{ }^{\circ} \mathrm{C}$. In a third step platinum was deposited from a hexachloroplatinic acid solution to obtain a platinum content between 0.05 and $0.3 \mathrm{wt} \%$. In this work, the catalyst used was $0.1 \mathrm{wt} \% \mathrm{Pt}$ and calcination at $700{ }^{\circ} \mathrm{C}$ in air, the sample was named $0.1 \% \mathrm{Pt}-15 \%-\mathrm{NiMgAl}_{2} \mathrm{O}_{4} \# 700^{\circ} \mathrm{C}$.

\subsection{Catalysts characterization}

Samples were characterized (before and after the catalyst tests) by $\mathrm{N}_{2}$ adsorption/desorption isotherms obtained at the temperature of liquid nitrogen in an automated physisorption instrument (Autosorb-1C, Quantachrome Instrument). Prior to the measurement, the samples were outgassed under vacuum at $200^{\circ} \mathrm{C}$ for $2 \mathrm{~h}$. Specific surface areas were calculated according to the Brunauer-Emmett-Teller (BET) method and the pore size distributions were obtained according to the Barret-Joyner-Halenda (BJH) method, from the adsorption data.

Temperature programmed reduction (TPR) analysis was performed in a quartz reactor under 5 vol\% $\mathrm{H}_{2} / \mathrm{N}_{2}$ flow $(30 \mathrm{~mL} / \mathrm{min})$ from 30 to $920^{\circ} \mathrm{C}$ at a heating rate of $5^{\circ} \mathrm{C} / \mathrm{min}$. A thermal conductivity detector (TCD) was used to monitor the $\mathrm{H}_{2}$ consumption. APM $5 \mathrm{~A}$ column was user to trap water formed during the process.

The crystalline phases (of freshly prepared catalysts and their reduced forms) were characterized by X-ray diffraction (XRD) in a Siemens D-5000, with graphite monochromated $\mathrm{Cu} K \alpha$ irradiation.

The sample morphology was observed with scanning electron microscope (SEM) obtained with a Philips XL30 scanning microscope operating at an accelerating voltage of $20 \mathrm{kV}$ and transmission electron microscope (TEM JEM - 1011) operating at an accelerating voltage of $120 \mathrm{kV}$ and Raman spectroscopy obtained with a Raman spectrometer (Renishaw - RGH22) with a Ar laser wavelength of $514.5 \mathrm{~nm}$.

\subsection{Catalysts testing}

The decomposition reaction of $\mathrm{CH}_{4}$ was carried out in a quartztube fixed bed flow reactor heated by an electric furnace (Fig. 1 ). The $0.1 \% \mathrm{Pt}-15 \% \mathrm{Ni} / \mathrm{MgAl}_{2} \mathrm{O}_{4}$ catalysts $(100 \mathrm{mg})$ were pre-treated in situ in a $\mathrm{H}_{2}$ stream at $700^{\circ} \mathrm{C}$ with a heating rate of $10^{\circ} \mathrm{C} \mathrm{min}-1$ for $1 \mathrm{~h}$ or $3 \mathrm{~h}$. The experiments were conducted under atmospheric pressure at 550 and $700{ }^{\circ} \mathrm{C}$. The reaction gas was composed of $\mathrm{N}_{2}$ and $\mathrm{CH}_{4}$ in 7:1 molar ratio $\left(\mathrm{N}_{2}: \mathrm{CH}_{4}\right)$. The total flow rate of the reaction gas was

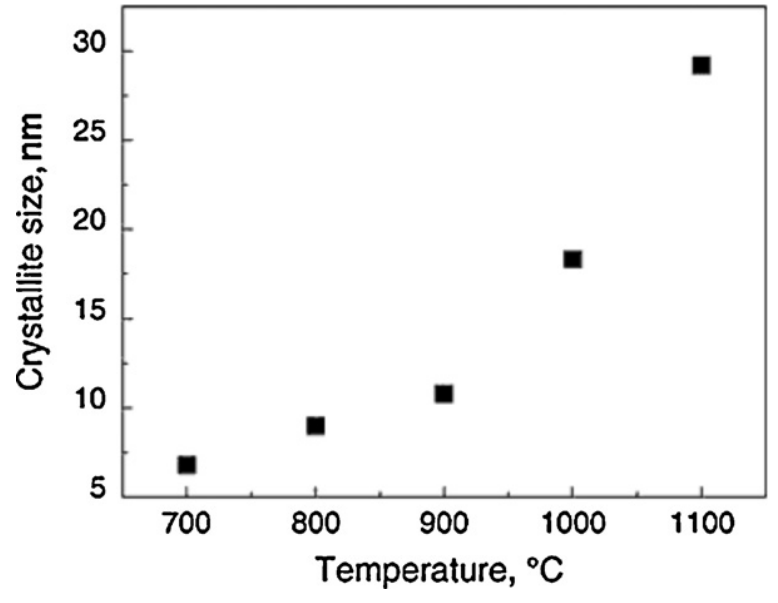

Fig. 2. Crystallites size of the spinel powder, as a function of the calcination temperature.

$80 \mathrm{~mL} \mathrm{~min}^{-1}$. The reactant and the product gases were analyzed with a Shimadzu GC-8A gas chromatograph, equipped with a thermal conductivity detector, a Porapak-Q column and a 5A molecular sieve column with Ar as the carrier gas.

Nitrogen was used as a diluent and as an internal analysis standard. Catalytic activity was evaluated in terms of methane conversion defined as

$\mathrm{C}\left(\mathrm{CH}_{4}\right)(\%)=\frac{Q_{\text {conv }}}{Q_{\mathrm{CH}_{4}}} \times 100$

where $Q_{\text {conv }}$ represents the quantity (moles) of converted methane; $\mathrm{Q}_{\mathrm{CH}_{4}}$ represents the total quantity (moles) of methane fed into the reactor.

\section{Results and discussion}

In Fig. 2 the crystallites size of the spinel powder as a function of the calcination temperature is presented. Until a temperature of $950^{\circ} \mathrm{C}$, small particles $(\varnothing<12 \mathrm{~nm})$ are obtained and at higher temperatures there is a significant increase of the crystallites size (about $30 \mathrm{~nm}$ at $1100^{\circ} \mathrm{C}$ ) Folleto et al. [4].

Fig. 3 shows the X-ray diffractograms of the precursor and calcinated samples at temperatures between 600 and $1100^{\circ} \mathrm{C}$.

It can be seen that the precursor, which is a mixture of aluminium and magnesium hydroxides, is an amorphous material. After calcination at $600^{\circ} \mathrm{C}$ the formation of the spinel phase

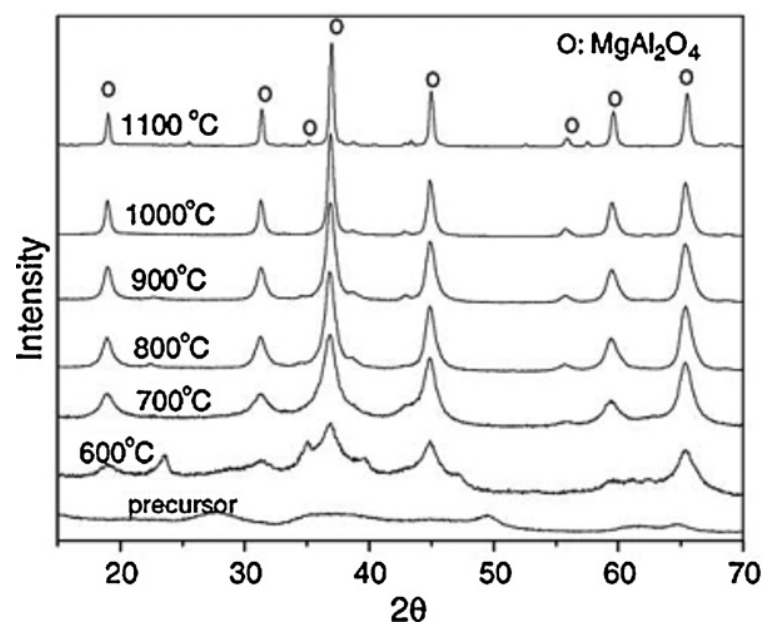

Fig. 3. Diffractograms of precursor and calcinated samples. 


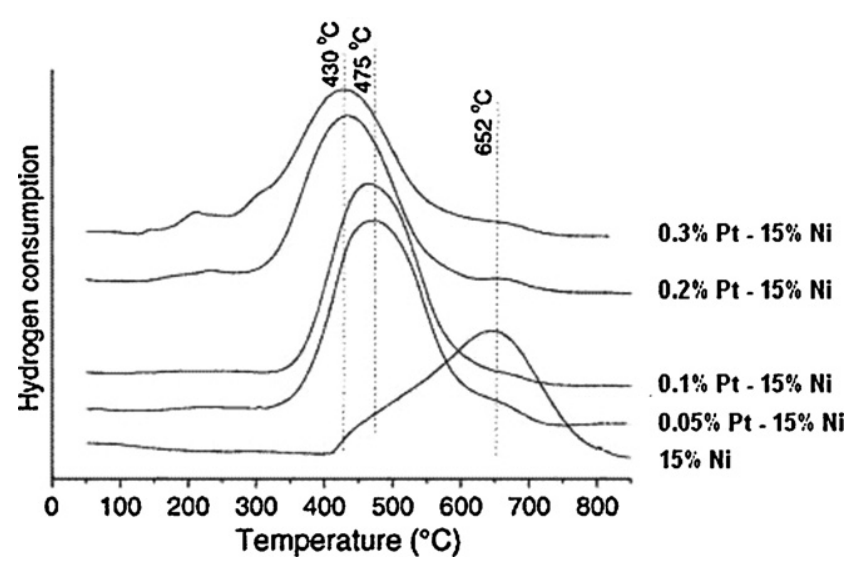

Fig. 4. TPR analysis of catalysts.

occurs. However, there also appeared some impurities, probably the presence of aluminium and magnesium hydroxides, which were not converted. Nevertheless, calcination at a temperature of $700^{\circ} \mathrm{C}$ or higher promoted the formation of a pure spinel phase [4].

Fig. 4 shows the TPR profiles for the Ni and Pt catalysts.

TPR profiles presented in Fig. 4 show that the addition of platinum favour as expected the reduction of nickel oxide particles (spill-over mechanism). It was observed that by adding a small amount of $\mathrm{Pt}(0.05 \%)$ to a $15 \%-\mathrm{NiMgAl}_{2} \mathrm{O}_{4}$, the reduction temperature decreases from 652 to $475^{\circ} \mathrm{C}$ ). When a higher amount of Pt was added, for example, $0.3 \%$, the reduction temperature decreased to $430^{\circ} \mathrm{C}$ in relation to the sample with $15 \% \mathrm{Ni}$ which confirmed the spill-over effect [4].

In order to investigate the catalytic activity of the $0.1 \% \mathrm{Pt}-15 \%-\mathrm{NiMgAl}_{2} \mathrm{O}_{4} \# 700^{\circ} \mathrm{C}$ catalyst the decomposition reaction of methane was carried out. Fig. 5 shows the catalyst behaviour with different $\mathrm{N}_{2}: \mathrm{CH}_{4}$ molar ratios.

The results showed that under a feed flow condition where methane was more diluted, the catalyst gave the highest initial catalytic activity value (14\%). On the other hand, when the methane was very concentrated in the reaction feed flow, that is, using a $\left(\mathrm{N}_{2}: \mathrm{CH}_{4}\right)$ molar ratio of $1: 3$ the catalyst gave the initial catalytic activity value of $8 \%$. In both reactions, initial catalytic activities were followed by a rapid drop until a total loss of activity after $85 \mathrm{~min}$.

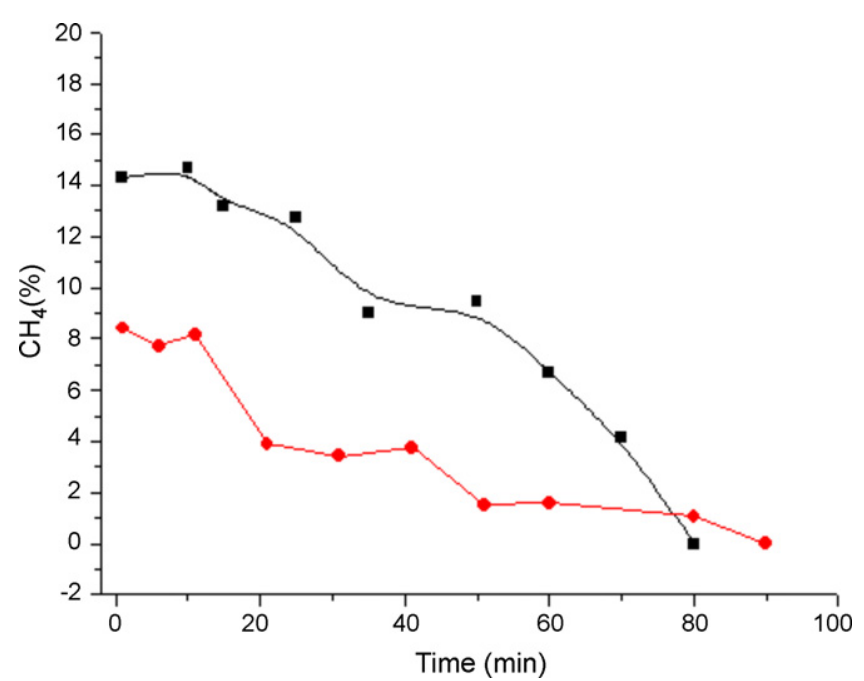

Fig. 5. Methane decomposition over $0.1 \% \mathrm{Pt}-15 \% \mathrm{Ni}-\mathrm{MgAl}_{2} \mathrm{O}_{4} \# 700$ catalyst. $\mathrm{N}_{2}: \mathrm{CH}_{4}$

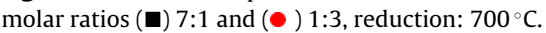

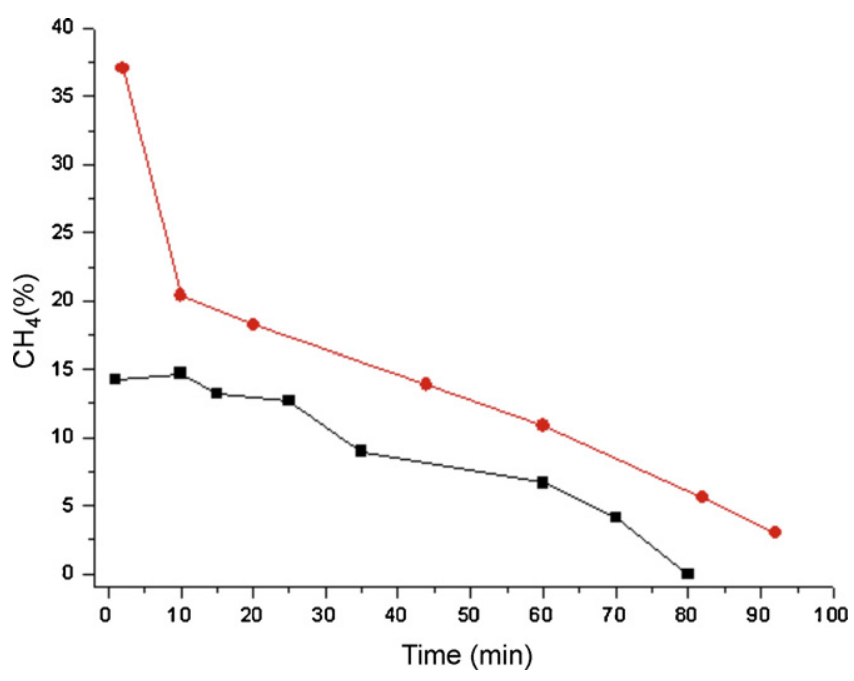

Fig. 6. Methane decomposition over $0.1 \% \mathrm{Pt}-15 \% \mathrm{Ni}-\mathrm{MgAl}_{2} \mathrm{O}_{4} \# 700$ catalyst in the $\mathrm{CH}_{4}$ conversion at $550^{\circ} \mathrm{C}$. Effect of the reduction rate: (ם) $1 \mathrm{~h}$ and ( ) $3 \mathrm{~h}$; $\mathrm{N}_{2}: \mathrm{CH}_{4}=7: 1$; reduction, $700^{\circ} \mathrm{C}$.

Fig. 6 shows the effect of the reduction rate of a $0.1 \% \mathrm{Pt}-15 \%-\mathrm{NiMgAl}_{2} \mathrm{O}_{4} \# 700{ }^{\circ} \mathrm{C}$ catalyst on methane decomposition.

It can be seen in Fig. 6 that the highest initial methane conversion value (37\%) was achieved by the catalyst reduced for $3 \mathrm{~h}$. When the catalyst was reduced for $1 \mathrm{~h}$ initial $\mathrm{CH}_{4}$ conversion was about $15 \%$. This catalyst ( $1 \mathrm{~h}$ ) showed initial methane conversion value of $14 \%$. However, both catalysts were followed by a rapid drop in activity due to carbon deposition at their surfaces, until a total deactivation after $80 \mathrm{~min}$ of reaction over the catalyst reduced for $1 \mathrm{~h}$.

The performance of the $0.1 \% \mathrm{Pt}-15 \%-\mathrm{NiMgAl}_{2} \mathrm{O}_{4} \# 700{ }^{\circ} \mathrm{C}$ catalyst on the methane decomposition at different temperatures can be seen in Fig. 7.

When the reaction was performed at $550^{\circ} \mathrm{C}$ the initial methane conversion was low (15\%), and the deactivation was rather rapid (i.e. after $80 \mathrm{~min}$ ) If the reaction temperature was increased to $700^{\circ} \mathrm{C}$, the initial reaction rate increased to $45 \%$, then a rapid decrease of $\mathrm{CH}_{4}$ conversion was observed in $20 \mathrm{~min}$ and the conversion decrease slowly until $240 \mathrm{~min}$. These results suggested that

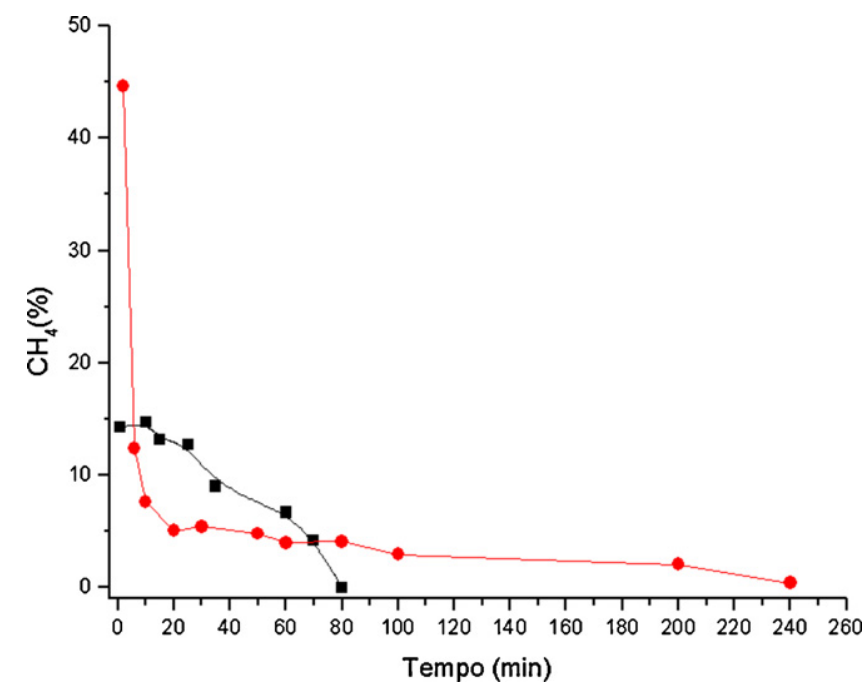

Fig. 7. Methane decomposition over $0.1 \% \mathrm{Pt}-15 \% \mathrm{Ni}-\mathrm{MgAl}_{2} \mathrm{O}_{4} \# 700$ catalyst in the $\mathrm{CH}_{4}$ conversion at different temperatures: (四 $550{ }^{\circ} \mathrm{C}$ and $(\bullet) 700^{\circ} \mathrm{C} ; \mathrm{N}_{2}: \mathrm{CH}_{4}=7: 1$; reduction, $700{ }^{\circ} \mathrm{C}$ 

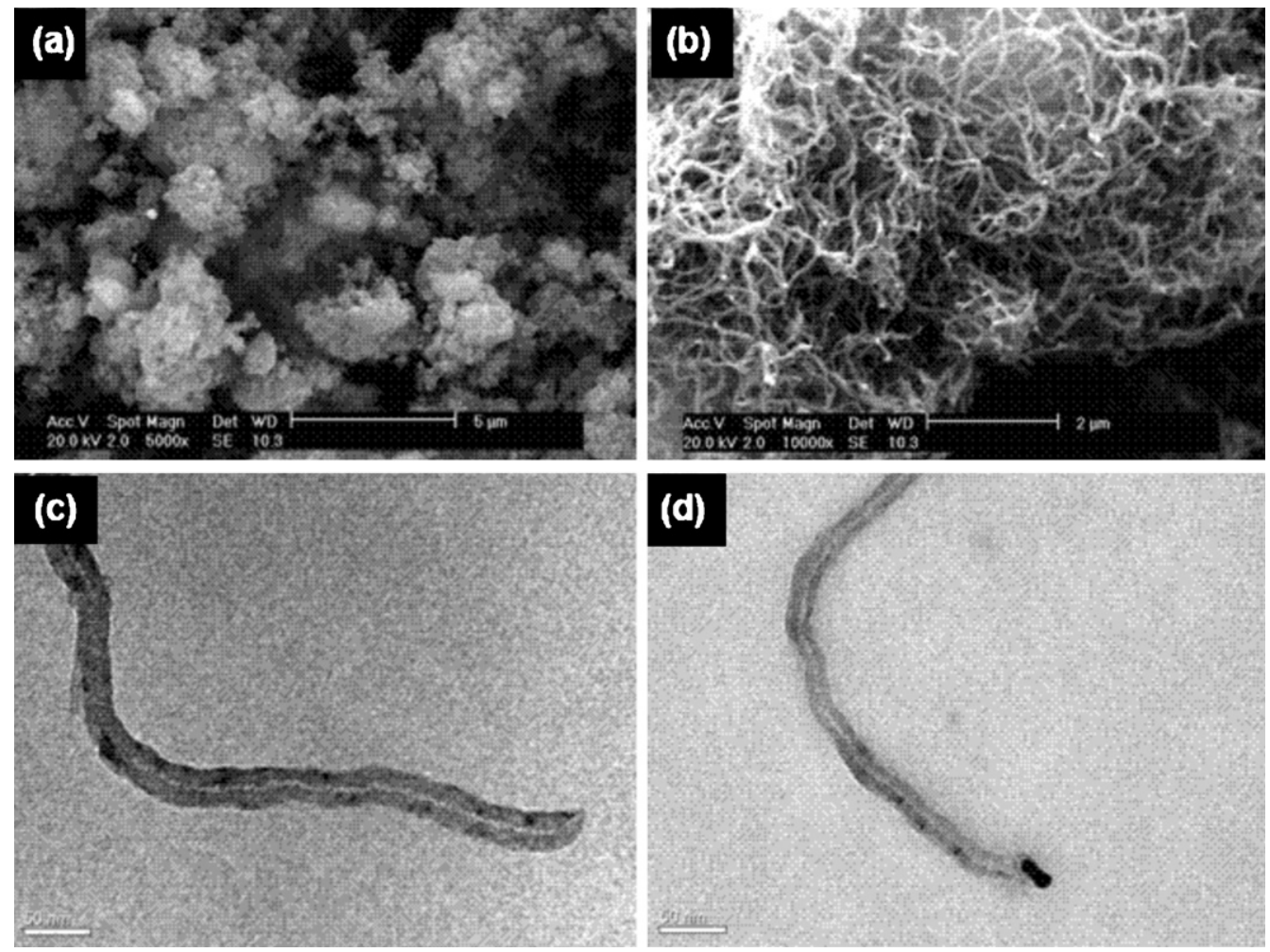

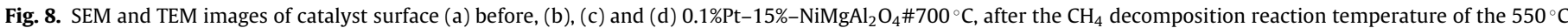
(reduced at $700^{\circ} \mathrm{C}$ for $1 \mathrm{~h}$ ).

different carbon species were formed according to the reaction temperature.

The SEM and TEM characterizations of the carbon-containing materials after the $\mathrm{CH}_{4}$ reaction are presents in Fig. 8. The main form of the carbonated deposition seems to be CNTs (Fig. 8b), nevertheless it was also noticed the formation of irregular carbon agglomerates.

Fig. $8 \mathrm{c}$ and $\mathrm{d}$ shows the end of MWCNTs with Pt-Ni particles (dark spots in Fig. 8d).

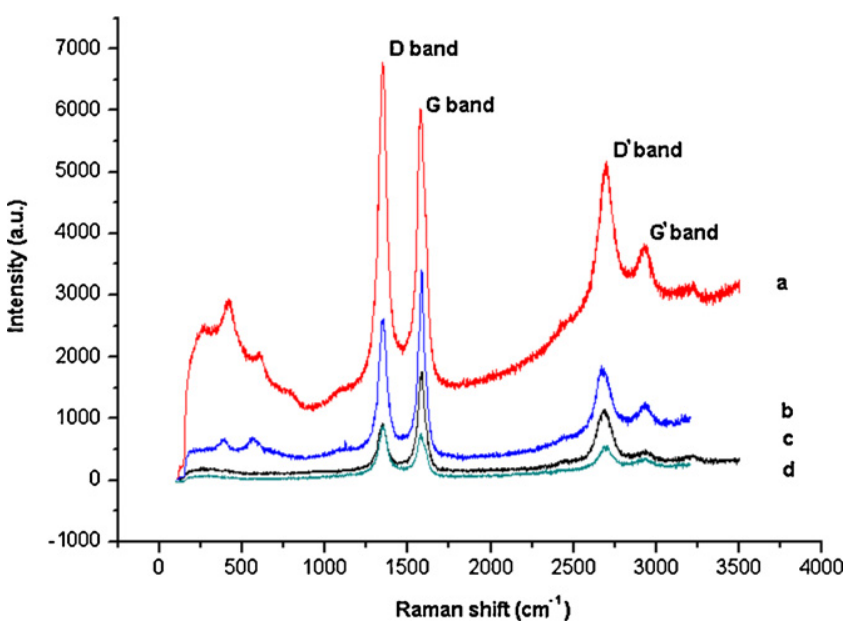

Fig. 9. Raman spectra of the $0.1 \% \mathrm{Pt}-15 \%-\mathrm{NiMgAl}_{2} \mathrm{O}_{4} \# 700{ }^{\circ} \mathrm{C}$ samples after the catalytic decomposition of methane (a) reduced at $700{ }^{\circ} \mathrm{C}$ for $3 \mathrm{~h}$ and reaction temperature of the $550{ }^{\circ} \mathrm{C}, \mathrm{N}_{2}: \mathrm{CH}_{4}=7: 1$, (b) reduced at $700^{\circ} \mathrm{C}$ for $1 \mathrm{~h}$ and reaction temperature of the $550{ }^{\circ} \mathrm{C}, \mathrm{N}_{2}: \mathrm{CH}_{4}=7: 1$, (c) reduced at $700^{\circ} \mathrm{C}$ for $1 \mathrm{~h}$ and reaction temperature of the $700{ }^{\circ} \mathrm{C}, \mathrm{N}_{2}: \mathrm{CH}_{4}=7: 1$ and (d) reduced at $700^{\circ} \mathrm{C}$ for $1 \mathrm{~h}$ and reaction temperature of the $550{ }^{\circ} \mathrm{C}, \mathrm{N}_{2}: \mathrm{CH}_{4}=1: 3$.
The Raman spectra of the catalyst after catalytic tests are shown in Fig. 9.

The spectra obtained with the $0.1 \% \mathrm{Pt}-15 \%-\mathrm{NiMgAl}_{2} \mathrm{O}_{4} \# 700^{\circ} \mathrm{C}$ catalyst reduced at $700^{\circ} \mathrm{C}$ for $1 \mathrm{~h}$ or $3 \mathrm{~h}$ at a reaction temperature of $550^{\circ} \mathrm{C}$ or $700^{\circ} \mathrm{C}$ with a $\mathrm{N}_{2} / \mathrm{CH}_{4}(7: 1$ and $1: 3)$ indicated the presence of bands originated from carbon structures.

Firstly the presence of a low frequency band, attributed to the radial breathing mode (RBM) of the carbon nanotubes, characteristic of single-walled nanotubes (SWNTs) Almeida et al. [5] was observed. The intensity of that band seems to indicate that the SWCNTs formation was rather low Zenga et al. [6].

Secondly the appearance of a D band around $1356 \mathrm{~cm}^{-1}$ was also a clear indication of the formation of multi-walled carbon nanotubes (MWCNTs) [6].

Furthermore, the ratio of ID/IG which could be related to the nature of CNTs gave some additive information about MWCNTs. Indeed a ID/IG ratio of 1.18 was observed for the experiment (Fig. 9b). While for the experiment (Fig. 9b) the ratio was only of 0.69 . This result indicates that after a partial reduction of the catalyst the graphitization degree was more important in agreement with the SEM and TEM images presented in Fig. 8.

If the reduction temperature was increased up to $700^{\circ} \mathrm{C}$, the formation of CNTs is less important and MWCNTs are mainly observed

\section{Conclusion}

The addition of a small amount of Pt to a nickel- $\mathrm{MgAl}_{2} \mathrm{O}_{4}$ catalyst promotes the formation of carbon nanotubes with a significant selectivity to MWCNT. The interest of using a bimetallic (Pt-Ni) catalyst is to favour the reduction of the Ni precursor (and the formation of small nickel particles).

For the catalyst that we prepared methane is mainly transformed into structured MWCNTs if the reduction is complete while 
graphitization is observed over partially reduced catalysts. A fine characterization of the catalyst surface after each step of the preparation and use is currently under investigation in order to progress in the relationships between the surface composition and the CNTs formation.

\section{Acknowledgements}

The authors are grateful to Universidade Federal de Santa Catarina (UFSC) and Conselho Nacional de Desenvolvimento Científico e Tecnológico (CNPQ) for financial support and the LCME - UFSC for the microscopies.

\section{References}

[1] Y.D. Li, J.L. Chen, Y.N. Qin, L. Chang, Energy Fuels 14 (2000) 1188

[2] H. Dai, A.G. Rinzler, P. Nikolaev, A. Thess, D.T. Colbert, R.E. Smalley, Chem. Phys. Lett. 260 (1996) 471

[3] S. Amelinckx, X.B. Zhang, D. Bernaerts, X.F. Zhang, V. Ivanov, B. Nagy, Science 265 (1995) 635.

[4] E.L. Foletto, R.W. Alves, S.L. Jahn, J. Power Sources 161 (2006) 531.

[5] R.M. Almeida, H.V. Fajardo, D.Z. Mezalira, G.B. Nuernberg, L.K. Noda, L.F.D. Probst, N.L.V. Carreño, J. Mol. Catal. A: Chem. 259 (2006) 328.

[6] L. Zenga, W. Wanga, D. Lei, J. Liang, H. Zhao, J. Zhao, X. Kong, Physica B 403 (2008) 2662. 